\title{
Sustainable tourism 2040
}

\author{
Albert Postma, Elena Cavagnaro and Ernesto Spruyt
}

\begin{abstract}
Purpose - In tourism, it is a challenge to connect the commercial (economic) interests of the industry with the creation of social and environmental values along the principles of sustainability. The purpose of this paper is to develop a framework that can inspire businesses to use sustainability as a leading principle for their commercial activities, by means of expert consultation.

Design/methodology/approach - A study was conducted in which sustainability, foresight and business identity featured as the guiding concepts. Data were collected by means of expert consultation.

Findings - The study resulted in four scenarios for a sustainable tourism ind ustry in 2040 which were framed by the key uncertainties driving this 2040 future. These scenarios offer a source of inspiration for tourism businesses to develop a proactive attitude and robust strategies for a sustainable yet competitive future. Subsequently, for each of the four business types (based on their identity or DNA) strategic questions were listed together with actionable strategic propositions with reference to sustainable development.

Research limitations/implications - Data were collected with a sample of partners in the European Tourism Futures Research Network (convenience sample).

Practical implications - The key strategic questions and actionable strategic propositions are presented for four different business styles that allow them to implement sustainability in a commercial way.

Originality/value - The connection between the core concepts of sustainability, foresight and business identity offers a novel approach to the field of sustainability.
\end{abstract}

Keywords Scenarios, Strategy, Foresight, Sustainable tourism, Business identity

Paper type Viewpoint

\section{Introduction}

The European Tourism Futures Institute (ETFI) was challenged by the idea of finding a new way to stimulate the sustainable development of tourism business practice. The ETFI together with its partners in the European Tourism Futures Research Network conducted a study that aimed to identify and elaborate four scenarios for a sustainable industry in 2040, in which for each of the four types of business identity the implications of these scenarios were mapped together with strategic questions with reference to sustainability and actionable strategic propositions. This resulted in a framework that might inspire businesses to use sustainability as a leading principle for their commercial activities. Thus, the study contributes to the managerial practice by offering a long-term future orientation (2040); an integral/systemic approach which goes beyond "everyday sustainable practices" and integrates social, environmental and economic values; a translation of the notion of sustainable development in concrete and tailor-made suggestions for strategic action.

The main concepts on which the study was based will be presented first: sustainability and sustainable tourism, complexity of the future and strategic foresight, and business identity and the DNA framework. In the section on sustainability and sustainable tourism the context and argument of the study will be outlined. Destatte (2010) stresses the suitability of foresight as a major tool for tackling sustainability; he even argues that "the aim of foresight is sustainable development in a changing world" (p. 1575). In the section on complexity of the future and foresight, the research method will be outlined and the four scenarios will be presented. Next, the scenarios will be connected to the DNA framework of business identity, which results in concrete strategic propositions concerning sustainable development for four different types of businesses. Finally, the main outcomes of the study will be presented.
Albert Postma is a Professor of Applied Sciences at the European Tourism Futures Institute, Stenden University of Applied Science, Leeuwarden, The Netherlands.

Elena Cavagnaro is a UAS Professor of Sustainability in Hospitality and Tourism at the Academy of International Hospitality Research, Stenden University of Applied Science, Leeuwarden, The Netherlands. Ernesto Spruyt is based at Freekick, Rotterdam, The Netherlands.

Received 20 October 2015 Revised 11 December 2015 25 January 2016 Accepted 6 February 2016

C Albert Postma, Elena Cavagnaro and Ernesto Spruyt. Published in the Journal of Tourism Futures.

This article is published under the Creative Commons Attribution (CC BY 4.0) licence. Anyone may reproduce, distribute, translate and create derivative works of this article (for both commercial and non-commercial purposes), subject to full attribution to the original publication and authors. The full terms of this licence may be seen at http://creativecommons.org/ licences/by/4.0/legalcode 


\section{Sustainability and sustainable tourism}

The call for a sustainable form of development is based on the observation that the way societies are organized worldwide is unsustainable or, in other words, it does not take into account Earth's natural limits and is not able - within these limits - to create well-being for the people both now and in the future (Cavagnaro and Curiel, 2012).

The awareness that the natural environment poses limits to growth and that societal collapse may follow if these limits are exceeded has been one of the first movers towards sustainability (Meadows et al., 1972). Recently, it has been proved that three out of ten critical natural boundaries have already been trespassed (Rockström et al., 2009). Among these limits some, for example climate change, have immediate implications for tourism, as will be briefly pointed out below.

Alongside an environmental dimension, sustainable development has an economic-social component. Since the 1970s, it was recognized that even if the environmental problem could be solved, to achieve sustainability social issues such as poverty reduction and capabilities' development also need to be addressed (see e.g. United Nations, 1962; Dag Hammarskjöld Foundation, 1975). As the annual report of the UN on the Millennium Development Goals shows, even though progress can be reported in most areas, there are still pressing social issues that need to be addressed especially but not exclusively, in developing countries (United Nations, 2013). Therefore, it may be concluded that our contemporary world is both socioeconomically and environmentally unsustainable.

This is true in general, and for specific industries such as tourism in particular. Tourism represents an interesting challenge for sustainability because it directly impacts on and is impacted by both the socio-economic and environmental dimension of sustainability. Tourism is a major economic force worldwide, accounting for 9 per cent of World GDP (United Nations World Tourism Organization (UNWTO), 2013). It has a major social impact as well. Looking, for example, at jobs, one in 11 is in tourism (UNWTO, 2013). Alongside the positive impacts on economy and society, tourism also presents a dim side. Jobs created by tourism are often seasonal and low paid. Moreover, it is widely recognized that tourism strongly impacts the hosting community - and that this impact is not by definition positive (Postma, 2013). On a similar theme, tourism is strongly dependent on a healthy natural environment, while its impacts on nature are often negative (Hall and Lew, 2009). Just to quote one figure, a 2005 study estimated that tourism contributes to worldwide carbon emissions by 5 per cent (United Nations World Tourism Organization, 2008). Climate change due to increasing carbon emissions is one of the three crucial natural boundaries that have already been exceeded following the study by Rockström et al. (2009), which has been referred to earlier. Tourism does not only impact climate change, but will increasingly feel the consequences of that same climate change: it is estimated that certain areas will become too hot for tourists, while other coastal destinations may be flooded (Becken and Hay, 2012).

Ensuring that tourism reduces its negative impacts and increases its positive impacts on the environmental and the socio-economic dimension of sustainability is the aim of the widely recognized classical definition of sustainable tourism proposed by the United Nations Environment Programme and United Nations World Tourism Organization (2005): sustainable tourism is a form of tourism "that takes full account of its current and future economic, social and environmental impacts, addressing the needs of visitors, the industry, the environment and host communities" (p. 12). Tourism organizations are therefore considered to act sustainably if they create value on an economic, social and environmental dimension, the triple bottom line of profit, people and planet proposed by Elkington (1997).

If the conclusion above, namely that the current development is financially, socially and environmentally unbalanced, is true, then it follows that the contemporary world in general and the tourism industry in particular have not yet been able to meet its own need without jeopardizing its future. Therefore, change is needed. Change in the context of sustainability has been the subject of dedicated studies. These studies point to the "goals of a system" as one of the main leverage points to change. "System" in these studies does not only refer to the ecological or economic system as a whole, but also to an individual, an organization, an industry or a specific society. With reference to business organizations, the point is that these tend to have a clear commercial goal: profit. If value creation on the people and planet dimension of sustainability is 
added as a goal, then the company will act differently, i.e. sustainably. It is essential of course that this change is not superficial and that sustainability goals are deeply embedded in the organizational goals (Meadows, 1997; Doppelt, 2003).

A system's goal can be acted upon via the development of a vision where sustainability is central. A vision is commonly defined as a powerful description of a desired future. In the context of sustainability, the future component should be long term, where long term means looking further than the next five to ten years (Meadows, 1997; Doppelt, 2003; Destatte, 2010). Here a difficulty arises: uncertainty increases with the length of the time considered. When uncertainty increases, developing a compelling vision and setting concrete goals to stimulate people to act sustainably becomes a daunting enterprise. The implementation of sustainability has suffered greatly from this difficulty, or in other words from the complexity of the future (Cavagnaro and Curiel, 2012).

\section{Complexity of the future and foresight}

As it has been concluded above, the notion of sustainable development focusses on the long-term future and organizations need to develop a long-term, future-oriented vision to engage in it. The future, especially the long-term future, is difficult to grasp. This is due to a number of reasons. First, the future is only partly achievable by human intervention, because man's influence is constrained by their decisions and behaviour in the past and in the present that casts a shadow on the future and by the paradigms on which the decisions are based (Postma, 2014). Second, tourism's complexity makes it difficult to grasp and thus to influence it. Tourism is very much intertwined with other demographic, economic, social, technological, ecological and political and institutional developments in the highly globalized and hyperconnected society; it is composed of a number of domains that are highly interconnected and interdependent (such as sports, hospitality, recreation, culture and arts, events, and travel), each with its own dynamics and perspectives (Cooper and Hall, 2008); the services and facilities in the tourism opportunity spectrum are owned, managed or influenced by a diversity of public, semi-public and private parties (Postma and Jenkins, 1997). Third, the dynamics in consumer demand and the vast increase of consumers' knowledge cause a lot of uncertainty with regard to the future (Buhalis and Costa, 2006).

In this study, foresight has been applied to sustainable tourism development in Europe by means of expert consultation. Foresight has developed as an alternative to forecasting since the 1960s, both in business practice (e.g. Shell) and in science (e.g. Bergman et al., 2010). Contrary to conventional forecasting, foresight embraces the complexity, dynamics and non-linearity of the contemporary world. In this approach, it is not the past and present that are projected into the future, but it is the future that is projected into the present. The driving forces of change and the key uncertainties are explored, and based on the outcomes scenarios are developed. Such scenarios are not statistical predictions but lively descriptions of plausible futures, and in this respect they reflect a vision as intended by Meadows (1997), Doppelt (2003) and Destatte (2010) as discussed in the previous section. As the scenarios are built upon the key uncertainties, all of the scenarios could materialize. Together the scenarios give an impression of how the world could look on the long term. Essentially, the challenge for businesses and organizations is to be prepared for all of these futures. By anticipating the future in this way business will be more future proof. It implies a change from reactive to proactive behaviour. Varum and Melo (2009) and Buhalis and Costa (2006) regards this essential for the competitive power of tourism organizations and tourism businesses.

Selected experts of the European Tourism Futures Network of leading European knowledge institutions were consulted by e-mail with the following questions:

What are, according to you, the most important drivers in the business environment that drive sustainable development of the tourism industry in the EU till 2040 (these forces could be demographic, economic, social/cultural, technological, ecological, or political/institutional/legal). Give a concise description and explanation of why you consider it a driving force.

An analysis of the answers to these questions resulted in a preliminary list of driving forces of change that was used as input for the next consultation round of these experts. By means of e-mail each expert was asked to select and rank the driving forces that are the most uncertain regarding its outcome or impact on sustainable tourism in 2040. They were asked to motivate their 
answers in order to develop an understanding of their perceptions. The experts were also asked to add new associations to the descriptions if needed. This second consultation round gave insight in the level of uncertainty of the various driving forces and the nature of these uncertainties.

Through an analysis of the results of both consultation rounds, two critical uncertainties were identified that, according to the experts, drive sustainable development of the tourism industry till 2040 together with the opposite directions towards which these uncertainties could develop. Critical uncertainties refer to those driving forces of change that are both very important and very uncertain regarding its outcome. The two critical uncertainties that were identified are the geopolitical situation in Europe, and Europe's resource base. The uncertainty of these factors was expressed by describing the two extreme directions to which both could plausibly develop by 2040 . The geopolitical situation could either lead to a relatively strong economic position of the EU or an economic position that is lagging behind. The resource base could either lead to complete reliance on conventional resources or complete reliance on (new) sustainable resources. The two aforementioned critical uncertainties with their opposite directions of development form the basis of a cross with two axes that frame four possible scenarios. These were labelled as: back to the 1970s, captured in fear, shoulders to the wheel and unique in the world. Figure 1 shows the scenarios cross. On the basis of the outcomes of the expert consultation and the causal loop diagram the scenarios were elaborated in consistent descriptions. These descriptions are given in Table I.

\section{Business identity and the DNA framework}

The integration of sustainability in a company's principles and strategy has received more attention during the last years (Cavagnaro and Curiel, 2012). Business strategy is about creating long-lasting competitive advantage over competition (Porter, 1985). To be successful businesses need to maximize the relevancy of the offering for their customers and the distinctiveness of the offering compared to other players in the market. In other words, they need both to meet the basic conditions necessary to compete in a market - the critical success factors - and to develop distinctive unique selling points that set them apart from the competition (Daniel, 1961; Levitt, 1986; Johnson and Friesen, 1995).

The specific mix of relevance and distinctiveness created by a business determines its position in the market, the so-called positioning (Trout, 1969; Ries and Trout, 1981). Positioning offers the starting point to develop competitive advantage (Trout and Rivkin, 1996). It has been stated that when the positioning is clear, the strategy - including a sustainability strategy and policies - will follow (Van Eck et al., 2008).

\section{Figure 1 Framework with four scenarios for a sustainable tourism industry by 2040}

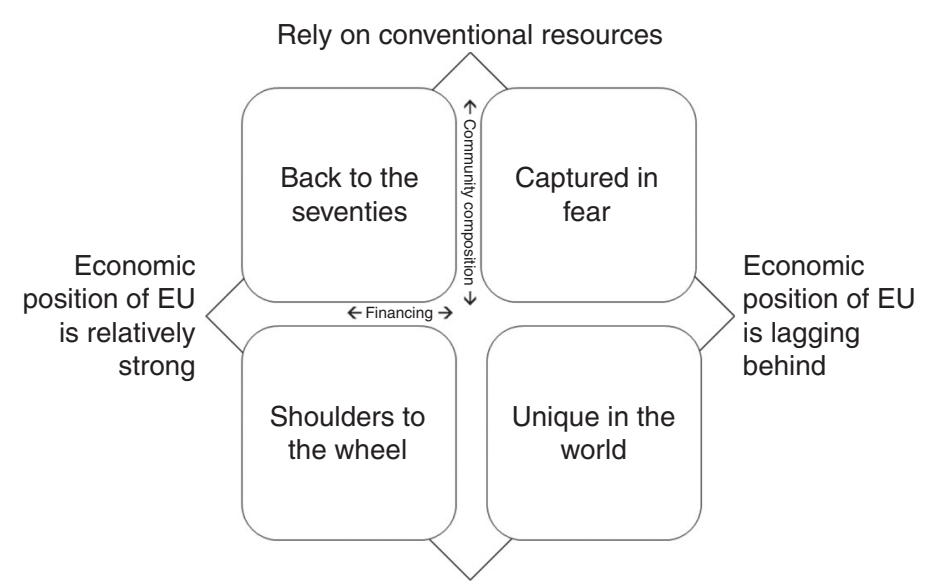

Rely on (new) sustainable resources 
"Back to the seventies"

The European economy grows faster than in the so-called emerging economies. This leads to a substantial increase in demand for energy. Time for the development of renewable resources is up and to be able to meet the vast growth of energy demand, there is a revival of the growth paradigm, at the costs of sustainable thinking, both within the market and the public sector. There is general support to invest in the development of conventional resources such as shale gas. The environmental lobby is increasingly worried and afraid that the ecosystem becomes irreparably damaged.

The tourism industry believes that the management of concentrated mass tourism is more durable than the old school of small-scale localized tourism

"Shoulders to the wheel"

Sooner than expected, the growth of the emerging economies has come to an end. Consequently, the relative economic power of Europe has increased, although the EU has not completely recovered from the consequences of the crisis yet. There is a clear revival of international trade and the Southern European countries benefit fully from it. Throughout Europe countries show an increase in wealth. The increasing competition on the world market makes the European tourism business inventive and cooperative, which gives an exponential boost to technological developments. The innovations are mainly aiming at stimulating sustainability. Putting al shoulders to the wheel is the general motto. The recession has resulted in the belief that sustainability is an important condition for further social and economic development

\section{"Captured in fear"}

The EU economy has still not climbed out of the valley. And as the economies of the BRIC countries and Northern Africa are booming, the backlog of Europe has only increased further. To protect the economy, the European Parliament has, with in its wake the different EU countries, taken a protectionist stance. This puts a brake on technological development, which not only disadvantages economic growth, but also prevents the development of technology for new resources and for the renewal of traditional resources. Thus, the ecosystem is increasingly at risk. Also socially, developments in Europe are not going smoothly: prosperity and welfare are under pressure. To prevent the fat in the fire, the mass media are placed under control, which hampers exchange of ideas, creativity and innovation in the tourism sector. Governments and oligopolists try to control the situation my means of a centralized management of resources

"Unique in the world"

Economic growth in the BRIC countries and Northern Africa proceeds, and, slowly but surely, Europe recovers from the recession, although the backlog of Europe is final. Prosperity and welfare in Europe are on the rise again, which creates a positive mood. To give the domestic industry a boost the EU pursues a protectionist policy in conjunction with stimulating exports, which also benefits tourism. The notion prevails that Europe can distinguish and gain global competitive advantage by focussing completely on sustainable resources. Moreover, this would stop the degradation of and maybe even all restore the natural environment. The business participates in the international agreements that are made in Europe with regard to sustainability. To stimulate national and regional production and consumption patterns, and to boost social, economic and environmental sustainability, decision making is decentralized yet centrally coordinated (sharing economy). Small-scale tourism is seen as more durable than localized mass tourism

In line with the definition of a sustainable organization reminded above (Elkington, 1997), Porter and Kramer $(2006,2011)$ propose that sustainability policies can only be successful in the long run if they simultaneously create value for society and for the organization itself. Addressing sustainability from a strategic perspective does not only imply redistribution of value, through, for example, philanthropy, but through shared value creation (Porter and Kramer, 2006, 2011).

Concluding the discussion so far, it can be argued that in integrating sustainability into the core strategy, organizations face two challenges. The first is how to make sustainability relevant for the customers; the second how to use sustainability as a distinguishing factor related to the competition.

Research shows (Gfk Panel Services Benelux, 2009; Trendbox, 2011) that people generally have a positive attitude towards sustainability, but that sustainability is only relevant as a buying motive for a small, stable group representing 2-5 per cent of sales per category. In order to make sustainability relevant for the majority of customers, it should be integrated with existing buying motives (Willems, 2011). In other words, sustainability should not be presented as a separate "benefit". The key here is to create value for customers with product's features that "others" 
would label sustainable, but that are being presented as "reason to believe" connected to other, more relevant benefits that customers are seeking. For example, "sustainability" can be successfully used as proof of a product's quality or innovativeness (Willems, 2012). The first question posed above has been at least tentatively answered.

The second question of how a business should use sustainability to distinguish itself from the competition can be answered by linking sustainability with an organization's identity in the process of (re)positioning the organizations. In this context, it should be noted first that organizations that have a clear sense of identity and use it as a starting point to shape all their policies and activities perform significantly better than companies that do not (Harter et al., 2004; Moers, 2007; Voskuyl, 2009) The implication is that identity is the most logical and hard-to-copy carrier for strategic distinctiveness. The Herrmann Brain Dominance Model is widely used to support organizations in analysing and further strengthening their identity (Herrmann, 1996). Using this model, Driessen (2005) describes four archetypal entrepreneurs, and consequently, four types of organizations that he labels as: the pioneer, the salesman, the manager and the professional.

When applying the Hermann Brain Dominance model to the concept of organizational identity, four quadrants can be derived from two axes. The horizontal axis represents a continuum between seeking risk vs the need for control. Some companies are more focussed on creating and chasing opportunities, and others more on bringing under control and managing their existing position in the market. The vertical axis represents a continuum between the tendency to rely on logical frameworks to support decision making vs the tendency to rely on the social context. The four quadrants are illustrated in Figure 2.

The resulting four quadrants, each with a distinctive colour, illustrate the identity or "DNA" of an organization. The DNA framework offers a typology of businesses that can be used in order to integrate sustainability at the core of a company, without jeopardizing the uniqueness of its business identity. In Table II, the four types of DNA are briefly described together with the strategic questions concerning sustainability.

Each of the four DNA profiles can be used as a starting point for developing a distinctive positioning in connection with sustainability. During the annual conference of the European Tourism Futures Research Network in 2014, a workshop was provided for the entire network plus a few other experts. During the workshop, the participants were asked to discuss the links between the scenarios and the four types of business identity. Table III was made on the basis of the results of this workshop. The table shows which direction tourism businesses with a certain identity have to take in making their

Figure 2 Framework with four types of organizational DNA

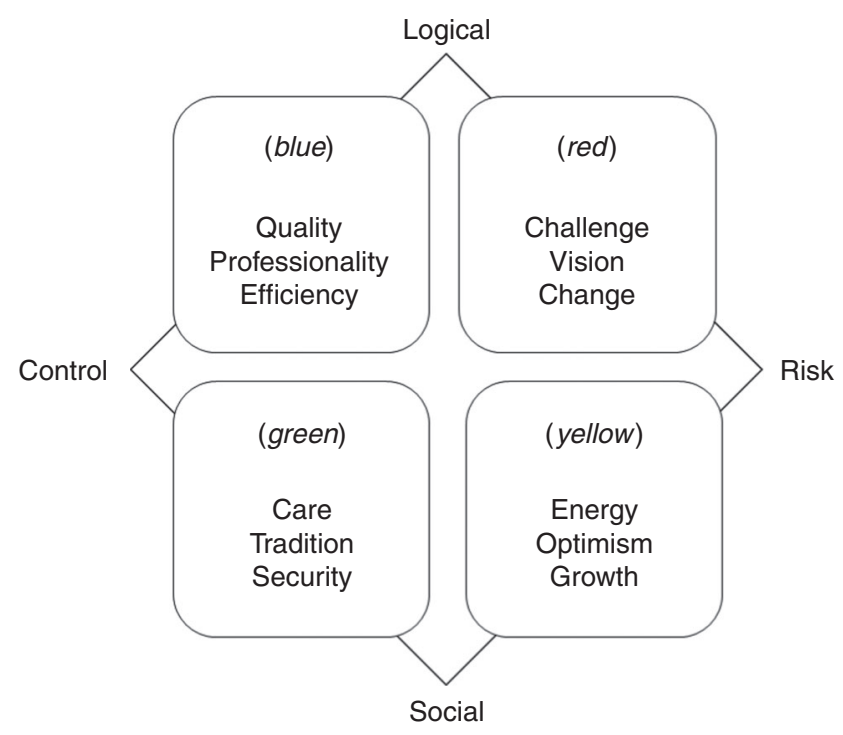


Red The tendency of red companies is to break out of In developing sustainability policies, RED traditional paradigms. They act in a self-conscious companies ask themselves: manner, independent of others. Culture is Is the policy conceptual, pioneering and generally informal, with loose, principle-based unconventional? procedures and a lot of delegated responsibility Does it show that sustainability can be achieved through vision, experimentation and courage? Does the policy provide the freedom and autonomy that my organization needs to be successful?

Yellow Imagination and making things attractive for a In developing sustainability policies, YELLOW larger public is what yellow companies are good at. Yellow companies are often trendsetters. companies ask themselves: They act in an upbeat, energetic way. Culture is generally very dynamic, with a flexible, marketoriented organization and short-communication lines Is the policy creative, optimistic and open hearted?

Does it show that sustainability can be achieved through enthusiasm, inspiration and optimism?

Does the policy provide the flexibility and dynamics that my organization needs to be successful?

Green The green company is conservative by nature. It is In developing sustainability policies, GREEN a trusted and familiar source for its customers. Green organizations build solid networks of relationships, with formalized structures. A safe working environment and atmosphere is very companies ask themselves: Is the policy unburdening, responsible and connective? important for green culture, as are clear rules and achieved through cooperation, formalization agreements

Does it show that sustainability can be and conformity?

Does the policy provide the stability and consensus that my organization needs to be successful?

Blue A drive for quality is what distinguishes the blue In developing sustainability policies, BLUE company. These companies are often specialists, companies ask themselves:

bringing a specific product or niche to perfection. Is the policy professional, practical and goal Blue organizations tend to be highly structured oriented? and organized, reaching high levels of efficiency. Does it show that sustainability can be Culture is serious and dedicated, within a highly achieved through efficiency, intelligence and formalized and predictive set of rules and dedication? procedures Does the policy provide the focus and structure that my organization needs to be successful?

company more sustainable, within the context of four different scenarios. Thus, future points were identified that describe the key strategic guidelines to achieve competitive advantage in relation to sustainable development. The future points can be used as guidelines to develop a compelling, future-directed, company-specific vision to foster change towards sustainability.

\section{Conclusions}

The aim of the study that is described in this paper is to emphasize how sustainable development could guide tourist businesses to become more competitive, while contributing to better quality of life now and in the future. The emerging scenario planning approach of foresight was used to develop four scenarios that paint a picture of four plausible futures of a sustainable tourism industry in 2040. Within the framework of each of the scenarios for four distinct types of organizational identity a vision and actionable strategic propositions are formulated.

The study offers a long-term future orientation (2040) - an integral/systemic approach which goes beyond "everyday sustainable practices" by integrating social, environmental and economic values into business strategies and operations. For four types of organizations, the study offers concrete and tailor-made suggestions for strategic action. 
Table III Future points for achieving competitive advantage in relation to sustainability, for four DNA profiles within the context of four scenarios for a sustainable tourism industry in 2040

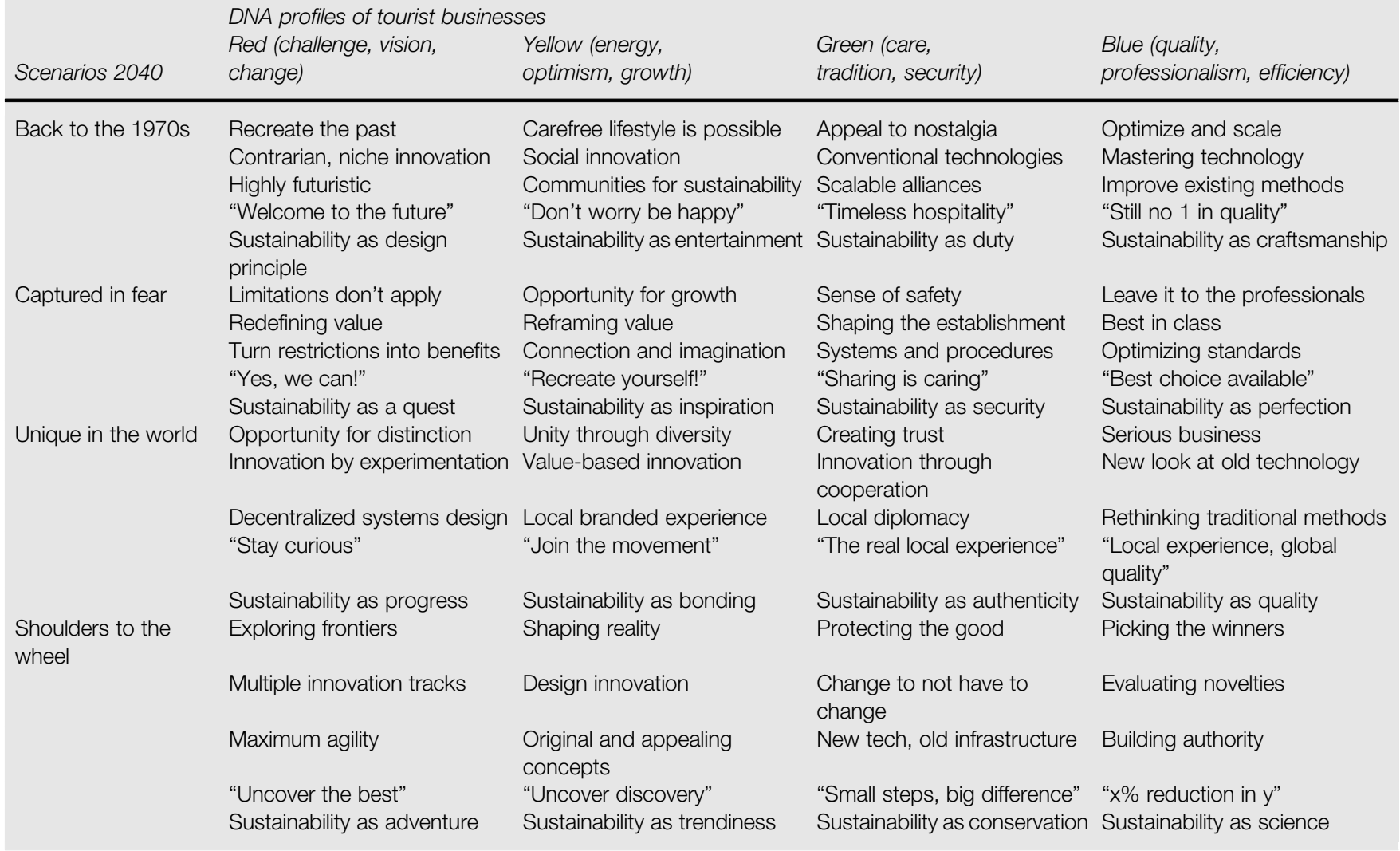

The outcomes should form the input for further discussion of individual companies. For a sustainable future they should be prepared for all scenarios and develop courses of action accordingly. Ideally this requires a process-oriented approach in which various stakeholders are involved. This allows the business to explore future uncertainties collectively, to exchange and discuss different interests, opinions and experiences, to learn from each other, and to stretch and challenge the thinking process, break paradigms and develop skills and competencies to deal with the complex future. Such a process-oriented approach to strategic planning fits into broader developments of democratization, knowledge development and learning (c.f. adaptive organizational leaning) (Postma, 2014).

The approach has foresight and offers a valuable way to be applied to geographical areas other than the EU, and to other industries.

\section{References}

Becken, S. and Hay, J. (2012), Climate Change and Tourism: From Policy to Practice, Routledge, Oxon.

Bergman, A., Karlsson, J.Ch. and Axelsson, J. (2010), "Truth claims and explanatory claims - an ontological typology of futures studies”, Futures, Vol. 42 No. 8, pp. 857-65.

Buhalis, D. and Costa, C. (Eds), (2006), Tourism Business Frontiers. Consumers, Products and Industry, Elsevier/Butterworth Heinemann, Oxford.

Cavagnaro, E. and Curiel, G. (2012), The Three Levels of Sustainability, Greenleaf Publishing, Sheffield.

Cooper, C. and Hall, C.M. (2008), Contemporary Tourism. An International Approach, ButterworthHeinemann/Elsevier, Oxford.

Dag Hammarskjöld Foundation (1975), "What now? Another development: report on development and international co-operation”, Development Dialogue, Vols 1/2, Special Issue, 128pp.

Daniel, D.R. (1961), "Management information crisis”, Harvard Business Review, Vol. 39 No. 5, pp. 111-21. 
Destatte, P. (2010), "Foresight: a major tool in tackling sustainable development", Technological Forecasting \& Social Change, Vol. 77 No. 9, pp. 1575-87.

Doppelt, B. (2003), Leading Change Toward Sustainability: A Change-Management Guide for Business, Government and Civil Society, Greenleaf Publishing, Sheffield.

Driessen, M.P. (2005), "E-Scan Ondernemerstest: beoordeling en ontwikkeling ondernemers competentie", PhD thesis, University of Groningen, Groningen, available at: http://irs.ub.rug.nl/ppn/289323711 (accessed 15 November 2013).

Elkington, J. (1997), Cannibals with Forks, The Triple Bottom Line of the 21st Century Business, Capstone, Chichester.

Gfk Panel Services Benelux (2009), De Duurzame Consumptie Monitor 2009, Gfk, Dongen.

Hall, C. and Lew, A. (2009), Understanding and Managing Tourism Impacts: An Integrated Approach, Routledge, London.

Harter, G., Koster, A. and Peterson, M. (2004), Managing Brands for Value Creation, Booz Allen Hamilton, Stuttgart, available at: www.booz.com/media/uploads/Managing_Brands_for_Value_Creation.pdf (accessed 15 November 2013).

Herrmann, N. (1996), The Whole Brain Business Book: Harnessing the Power of the Whole Brain Organization and the Whole Brain Individual, McGraw-Hill Education, Maidenhead.

Johnson, J.A. and Friesen, M. (1995), The Success Paradigm: Creating Organizational Effectiveness through Quality and Strategy, Quorum Books, New York, NY.

Levitt, T. (1986), The Marketing Imagination (new, expanded ed), Free Press, New York, NY.

Meadows, D.H. (1997), Places to Intervene in a System, Whole Earth, Sausalito, CA, available at: www. wholeearth.com/issue/2091/article/27/places.to.intervene.in.a.system (accessed 28 November 2013).

Meadows, D.H., Meadows, D.L., Randers, J. and Behrens, W.W. III (1972), The Limits to Growth, Pan Books, London.

Moers, P. (2007), Merk toch hoe sterk. Het merk als strategische factor tot succes, Kluwer, Deventer.

Porter, M.E. (1985), Competitive Advantage: Creating and Sustaining Superior Performance, The Free Press, New York, NY.

Porter, M.E. and Kramer, M.R. (2006), "Strategy and society: the link between competitive advantage and corporate social responsibility", Harvard Business Review, Vol. 84 No. 12, pp. 78-92.

Porter, M.E. and Kramer, M.R. (2011), "Creating shared value", Harvard Business Review, Vol. 89 Nos 1-2, pp. 62-77.

Postma, A. (2013), "'When the tourist flew in', critical encounters in the development of tourism”, PhD thesis, Faculty of Spatial Sciences, University of Groningen, Groningen.

Postma, A. (2014), “Anticipating the future of European tourism”, in Yeoman, I., Postma, A. and Oskam, J. (Eds), The Future of European Tourism, European Tourism Futures Institute, Stenden University of Applied Sciences, Leeuwarden, pp. 290-305.

Postma, A. and Jenkins, A.K. (1997), "Improving the tourists' experience: quality management applied to tourist destinations", in Murphy, P.E. (Ed.), Quality Management in Urban Tourism, John Wiley, New York, NY, pp. 183-98.

Ries, A. and Trout, J. (1981), Positioning, The Battle for Your Mind, Warner Books - McGraw-Hill, New York, NY.

Rockström, J., Steffen, W., Noone, K., Persson, Å., Chapin, F.S. III , Lambin, E.F., Lenton, T.M., Scheffer, M., Folke, C., Schellnhuber, H.J., Nykvist, B., de Wit, C.A., Hughes, T., van der Leeuw, S., Rodhe, H., Sörlin, S., Snyder, P.K., Costanza, R., Svedin, U., Falkenmark, M., Karlberg, L., Corel, R.W., Fabry, V.J., Hansen, J., Walker, B., Liverman, D., Richardson, K., Crutzen, P. and Foley, J.A. (2009), "A safe operating space for humanity", Nature, Vol. 461 No. 7263, pp. 472-5.

Trendbox (2011), Trendmonitor Life \& Living 2011, Trendbox, Amsterdam.

Trout, J. (1969), "'Positioning' is a game people play in today's me-too market place”, Industrial Marketing, Vol. 54 No. 6, pp. 51-5. 
Trout, J. and Rivkin, S. (1996), The New Positioning: The Latest on the Worlds \#1 Business Strategy, McGraw Hill, New York, NY.

United Nations (1962), The Development Decade: Proposals for Action (Sale No. 62.II B.2), UN Publications, New York, NY.

United Nations (2013), "The millennium development goals report”, United Nations, New York, NY.

United Nations Environment Programme and United Nations World Tourism Organization (2005), Making Tourism More Sustainable: A Guide for Policy Makers, UNEP/UNWTO, Paris/Madrid.

United Nations World Tourism Organization (2008), Climate Change and Tourism: Responding to Global Challenges, UNWTO, Madrid.

United Nations World Tourism Organization (UNWTO) (2013), Tourism Highlights, 2013 ed., UNWTO, Madrid.

Van Eck, M., Willems, N. and Leenhouts, E. (2008), Internal Branding in de Praktijk: het merk als kompas, Pearson Benelux, Amsterdam.

Varum, C.A. and Melo, C. (2009), "Directions in scenario planning literature - a review of the past decades", Futures, Vol. 42 No. 4, pp. 355-69.

Voskuyl, I. (2009), Merkoriëntatie als succesrecept, SWOCC, Amsterdam.

Willems, N. (2011), De ABC van marketing van duurzaamheid, Marketingonline, Amsterdam, available at: www.molblog.nl/bericht/de-abc-van-marketing-van-duurzaamheid/ (accessed 15 November 2013).

Willems, N. (2012), Duurzame marketing voor niet-duurzame consumenten, Business Openers, Laren, available at: http://businessopeners.nl/duurzame-marketing-voor-niet-duurzame-consumenten (accessed 15 November 2013).

\section{Further reading}

Heymann, E. and Ehmer, P. (2009), "Tourism 2030: climate change is re-charting the map of world tourism”, in Conrady, R. and Buck, M. (Eds), Trends and Issues in Global Tourism, Springer-Verlag, Berlin, pp. 39-56.

Lindgren, M. and Bandhold, H. (2009), Scenario Planning: The Link between Future and Strategy, Palgrave Macmillan, Basingstoke.

Veal, A.J. (1999), "Forecasting leisure and recreation”, in Jackson, E.L. and Burton, T.J. (Eds), Leisure Studies. Prospects for the Twenty-first Century, Venture Publishing Inc., State College, PA, pp. 385-98.

\section{Corresponding author}

Albert Postma can be contacted at: albert.postma@stenden.com

For instructions on how to order reprints of this article, please visit our website: 